\title{
SAPI PERAH: MASALAH DAN SOLUSI PENINGKATAN PRODUKSI SUSU (KASUS DI KELOMPOK TANI SEPAKAT II, DESA MOJOREJO, KABUPATEN REJANG LEBONG)
}

\section{DAIRY COW: PROBLEMS AND SOLUTIONS FOR INCREASING MILK PRODUCTION (CASE IN TANI SEPAKAT II GROUP, DESA MOJOREJO, REJANG LEBONG DISTRICT)}

\author{
Zul Efendi, Andi Ishak, Wahyuni A. Wulandari, dan Afrizon \\ Balai Pengkajian Teknologi Pertanian (BPTP) Bengkulu \\ Jl. Irian Km 6,5 Kota Bengkulu \\ Email: fzulefendi@yahoo.com
}

\begin{abstract}
ABSTRAK
Penelitian ini dilakukan pada bulan April sampai dengan Agustus 2019 pada Kelompok Ternak Sepakat II, Desa Mojorejo, Kecamatan Sindang Kelingi, Kabupaten Rejang Lebong. Tujuan penelitain adalah menganalisis permasalahan dan solusi peningkatan produksi susu sapi perah di kelompok tani Sepakat II Desa Mojorejo Kecamatan Sindang Kelingi, Kabupaten Rejang Lebong. Data yang dikumpulkan berupa data teknis, ekonomis, dan manajemen pemeliharaan sapi perah. Data teknis dan ekonomis yaitu jenis, sumber, nutrisi, dan biaya pakan. Data tentang jenis dan sumber pakan diperoleh dengan cara wawancara individu dan FGD. Kandungan nutrisi diperoleh melalui analisis laboratorium di Laboratorium Peternakan Universitas Bengkulu. Data manajemen pakan berupa analisis masalah dan solusi pemecahan masalah yang dikumpulkan melalui wawancara individu. Data dianalisis secara deskriptif dan menggunakan analisis pohon masalah serta AHP (Analitycal Hierarchy Process). Hasil yang didapatkan bahwa prioritas inovasi teknologi dalam rangka peningkatan produksi susu sapi perah di Kelompok Tani Sepakat II adalah Pemanfaatan konsentrat alternatif spesifik lokasi $(63,7 \%)$, Penanaman rumput unggul $(25,8 \%)$ dan Penyuluhan teknologi budidaya sapi perah $(10,5 \%)$.
\end{abstract}

Kata Kunci : Permasalahan; Solusi; Peningkatan; Produksi Susu; Sapi Perah.

\section{ABSTRACT}

This research was conducted in April to August 2019 at the Sepakat II Livestock Group, Mojorejo Village, Sindang Kelingi District, Rejang Lebong District. The purpose of this research is to analyze the problems and solutions to increase milk production in dairy cows in the Sepakat II farmer group in Mojorejo Village, Sindang Kelingi District, Rejang Lebong Regency. Data collected in the form of technical, economic and management data for dairy cattle maintenance. Technical and economic data, i.e. types, sources, nutrition, and feed costs. Data about the type and source of feed were obtained by means of individual interviews and FGDs. Nutrient content was obtained through laboratory analysis at the University of Bengkulu Animal Husbandry Laboratory. Feed management data is in the form of problem analysis and problem solving solutions collected through individual interviews. Data were analyzed descriptively and using problem tree analysis and AHP (Analitycal Hierarchy Process). The results obtained that the priority of technological innovation in the context of increasing milk production in dairy cows in the Sepakat II Farmers Group are the utilization of location-specific alternative concentrates (63.7\%), superior grass planting (25.8\%) and extension technology for dairy farming (10, 5\%).

Keywords: Problems, Solutions, Increase, Milk Production, Dairy Cows. 


\section{PENDAHULUAN}

Usaha peternakan sapi perah saat ini masih didominasi oleh usaha peternakan rakyat dengan manajemen tradisional dan skala pemilikan yang belum ekonomis, yaitu sekitar 1-4 ekor, dengan produksi susu yang masih rendah, yaitu rata-rata 10 liter per/ekor/hari. Hal ini mengakibatkan usaha budi daya sapi perah belum efisien, diperkirakan skala ekonomis dapat dicapai dengan kepemilikan 10-12 ekor sapi per peternak (Ahmad dan Hermiyetti, 2008) Kebutuhan susu yang meningkat merupakan salah satu faktor pendorong dalam perkembangan peternakan sapi perah di Indonesia. Selain itu kondisi geografis dan iklim di beberapa wilayah Indonesia memiliki karakteristik yang sesuai untuk ternak sapi perah.

Kabupaten Rejang Lebong merupakan salah satu kabupaten di Provinsi Bengkulu yang cocok untuk pengembangan sapi perah. Secara geografis, Kabupaten Rejang Lebong merupakan daerah dataran tinggi yang memiliki suhu yang dingin $\left(15-24^{0} \mathrm{C}\right)$ dan juga memiliki sumberdaya alam berupa hijauan rumput, limbah pertanian yang cukup banyak sebagai sumber pakan ternak sapi perah. Pada Tahun 2018, populasi ternak sapi perah di Kabupaten Rejang Lebong adalah sebanyak 116 ekor yang tersebar pada beberapa kecamatan.
Permasalahan yang dihadapi oleh peternak sapi perah adalah rendahnya produksi susu sapi, bahkan kualitas susunya tidak memenuhi standar industri pengolahan susu. Rendahnya produksi susu sapi perah selain faktor genetis juga dipengaruhi oleh faktor lingkungan, seperti manajemen pemeliharaan termasuk pemberian pakan dan kesehatan ternak. Sehingga peternak sapi perah tidak dapat menjalankan usaha tani sapi perahnya dengan baik.

Supaya peternakan sapi perah rakyat dapat meningkatkan produksinya, maka perlu dilakukan analisis permasalahan yang terdapat dalam budidaya ternak sapi perah tersebut dan usaha pemecahan yang dapat dilakukan.

\section{METODOLOGI}

Penelitian ini dilakukan pada bulan April sampai dengan Agustus 2019 pada Kelompok Ternak Sepakat II, Desa Mojorejo, Kecamatan Sindang Kelingi, Kabupaten Rejang Lebong. Kelompok ini termasuk binaan BPTP Bengkulu melalui kegiatan bioindustri kopi-sapi.

Data yang dikumpulkan berupa data teknis, ekonomis, dan manajemen pemeliharaan sapi perah. Data teknis dan ekonomis yaitu jenis, sumber, nutrisi, dan biaya pakan. Data tentang jenis dan sumber pakan diperoleh dengan cara wawancara individu dan FGD. 
Kandungan nutrisi diperoleh melalui analisis laboratorium di Laboratorium Peternakan Universitas Bengkulu. Data manajemen pakan berupa analisis masalah dan solusi pemecahan masalah yang dikumpulkan melalui wawancara individu. Data dianalisis secara deskriptif dan menggunakan analisis pohon masalah serta AHP (Analitycal Hierarchy Process).

Preferensi petani terhadap pola tanam sayuran yang berhubungan dengan aspek kelembagaan dianalisis dengan Analytical Hierarchy Process (AHP) menggunakan perangkat lunak Expert Choice-11. Input utama AHP adalah persepsi manusia (Sanyoto et al., 2017).

Menurut Iriadi dan Yohana (2016), metode AHP mampu memecahkan berbagai masalah pengambilan keputusan dengan pertimbangan berbagai kriteria. Model AHP disusun dengan pendekatan hirarki yang rasional dengan memasukkan seluruh pertimbangan yang dibutuhkan untuk pengambilan keputusan dan membandingkan nilai relatif antar berbagai komponen yang mempengaruhi keputusan (Handayani, 2015).

Tahapan dalam AHP yaitu menyusun hirarki, membuat penilaian (judgement), mengukur konsistensi, dan melakukan sintesis atau penarikan kesimpulan. AHP membantu membandingkan dua faktor penghambat penggunaan solid berdasarkan kepentingan relatifnya. Penilai kepentingan relatif dilakukan dengan mengkuantifikasi data kualitatif (faktorfaktor penghambat) ke dalam nilai komparasi dengan skala perbandingan (Saaty, 1993) yaitu 1). Sama penting, 3). Sedikit lebih penting, 5). Lebih penting, 7). Jauh lebih penting, 9). Sangat lebih penting. Sedangkan untuk 2, 4, 6 dan 8 adalah nilai antara.

\section{HASIL DAN PEMBAHASAN}

\section{Deskripsi Lokasi Penelitian}

Kabupaten Rejang Lebong merupakan salah satu wilayah di Provinsi Bengkulu yang berpotensi sebagai sentra pengembangan sapi perah. Hal ini karena Kabupaten Rejang Lebong memiliki sumberdaya yang mendukung budidaya sapi perah seperti suhu dan ketinggian tempat. Lingkungan budidaya sapi perah yang berasal dari wilayah subtropis membutuhkan suhu udara yang rendah pada ketinggian diatas 700 mdpl. Lingkungan ini ditemukan pada Kabupaten Rejang Lebong.

$$
\text { Kabupaten Rejang Lebong }
$$
memiliki agroekosistem basah dataran tinggi. Bulan-bulan terjadi hampir sepanjang tahun dengan suhu udara ratarata 15 - $24{ }^{\circ} \mathrm{C}$ (BPS Kabupaten Rejang Lebong, 2018). Pengembangan sapi perah cocok dilakukan pada beberapa kecamatan seperti Kecamatan Sindang 
Kelingi, Selupu Rejang, Bermani Ulu Raya, dan Padang Ulak Tanding. Jumlah sapi perah yang tercatat di Kabupaten Rejang Lebong pada saat ini sebanyak 116 ekor. Distribusi ternak sapi perah tersebut ada di beberapa desa seperti Desa Air Putih Kali Bandung, Air Duku, dan Mojorejo (BPS Kabupaten Rejang Lebong, 2018).

Kelompok Tani Sepakat II berdiri tahun 2010. yang diketuai oleh Bapak Mursalim dengan anggota sebanyak 15 orang. Mata pencaharian utama anggota kelompok tani adalah menanam sayuran disamping beternak sapi termasuk sapi perah. Pada tahun 2010. kelompok ini sudah mulai melakukan usaha ternak sapi perah namun banyak yang gagal dan pada tahun 2018 kelompok mendapatkan bantuan dari Dinas Peternakan dan Kesehatan Hewan Provinsi Bengkulu sebanyak 20 ekor. Populasi ternak sapi perah yang ada dikelompok tani Sepakat II pada saat ini sebanyak 65 ekor.

Sistem pemeliharaan sapi dilakukan dengan sistem intensif dimana ternak sapi dikandangkan sepanjang hari. Pemberian pakan dilakukan sebanyak 2 kali sehari (pagi dan sore hari), pemberian pakan tambahan (konsentrat) dilakukan pada ternak sapi yang sedang laktasi.
Pakan konsentrat yang diberikan pada ternak sapi perah yang sedang laktasi adalah ampas tahu, dedak padi dan kulit kopi. Ampas tahu biasanya di datangkan dari daerah Tebing Tinggi Provinsi Sumatera Selatan, Sedangkan dedak padi dan kulit kopi didapatkan dari daerah sekitar lokasi usaha peternakan.

\section{Permasalahan rendahnya produksi susu sapi perah}

Salah satu kelompok peternak sapi perah di Kabupaten Rejang Lebong adalah Kelompok Tani Sepakat II, Desa Mojorejo, Kecamatan Sindang Kelingi. Sapi perah yang dipelihara di kelompok tani ini berasal dari bantuan pemerintah pada tahun 2018 dengan jumlah 20 ekor untuk 4 orang petani ditambah sapi perah milik peternak yang sudah dibudidayakan. Pada saat ini, jumlah sapi perah di kelompok Sepakat II yaitu sebanyak 65 ekor dengan rincian pada Tabel 1.

Produksi susu rata-rata sapi perah pada kelompok ini adalah sekitar $7-8$ liter/ekor/hari, sedangkan potensi produksi sapi perah di Indonesia bisa mencapai Produksi rata-rata sapi perah di Indonesia hanya mencapai 10,7 liter per ekor per hari (3.264 liter per laktasi) (Chalid, 2006 dalam tawaf 2009). 
Tabel 1. Kepemilikan Ternak Sapi Perah di Kelompok Tani Sepakat II.

\begin{tabular}{clcccl}
\hline No. & $\begin{array}{c}\text { Nama } \\
\text { Peternak }\end{array}$ & $\begin{array}{c}\text { Jumlah } \\
\text { ternak } \\
\text { (ekor) }\end{array}$ & $\begin{array}{c}\text { Jumlah sapi } \\
\text { laktasi } \\
\text { (ekor) }\end{array}$ & $\begin{array}{c}\text { Jumlah produksi } \\
\text { susu/ekor/hari (liter) }\end{array}$ & Keterangan \\
\hline 1. & Mursalim & 40 & 4 & 7 & $\begin{array}{l}\text { Menggunakan } \\
\text { konsentrat }\end{array}$ \\
\hline 2. & Taryono & 10 & 1 & Tidak diperah & - \\
\hline 3. & Turkani & 6 & - & - & - \\
\hline 4. & Fauzi & 9 & - & - & - \\
\hline & Jumlah & 65 & 5 & & \\
\hline
\end{tabular}

Tingkat keuntungan dari ternak sapi perah menurun drastis ketika peternak tidak lagi mendapatkan bantuan konsentrat sejak tahun 2019. Akibatnya terjadi penurunan produksi susu bahkan sampai tidak lagi menghasilkan susu. Petani masih sulit untuk menyediakan konsentrat karena harga konsentrat jadi dari Pulau Jawa cukup mahal yaitu Rp. 4.500/kg. Padahal petani membutuhkan konsentrat 7-8 kg/ekor/hari. Sehingga rata-rata petani harus mengeluarkan biaya sekitar Rp. 25.000/ekor/hari. Biaya produksi susu akan semakin besar ketika dihitung biaya penyediaan hijauan dan pemeliharaan lainnya (memandikan ternak, memerah susu, dan membersihkan kandang). Total biaya pemeliharaan yang dikeluarkan oleh peternak sebesar Rp. 48.850/ekor/hari dengan rata-rata produksi susu sekitar 7 liter pada harga Rp. 8.500/liter. Ini berarti bahwa 1 ekor sapi perah hanya memberikan keuntungan sekitar Rp. 10.000/hari. Oleh karena itu, pemeliharaan sapi perah harus dalam jumlah yang banyak untuk mengejar peningkatan pendapatan petani. Keuntungan usaha ternak semakin menurun setelah petani tidak lagi mendapatkan bantuan konsentrat.
Permasalahan usaha ternak sapi perah di Kabupaten Rejang Lebong sangatlah kompleks. Hasil identifikasi melalui wawancara dengan petani mengindikasikan bahwa terdapat dua permasalahan pokok rendahnya produksi susu sapi perah yaitu kualitas induk yang kurang baik dan manajemen pemeliharaan yang belum sesuai dengan anjuran (Gambar 1).

Kualitas induk yang kurang baik disebabkan karena sejak awal pengadaan induk kurang sesuai dengan spesifikasi ternak yang diinginkan peternak. Spesikasi induk diantaranya terlihat pada bentuk tubuh dan bentuk ambing. Bentuk tubuh ternak secara visual kurang baik karena tidak segitiga. Selain itu, puting sapi tidak seluruhnya aktif sejak awal.

Dari sisi manajemen pemeliharaan, peternak belum memperhatikan kualitas pakan hijauan dan konsentrat yang sesuai dengan anjuran. Seringkali peternak memberikan pakan rumput lapangan dan jerami kepada 
ternaknya karena belum menanam rumput unggul. Sementara itu, pengadaan konsentrat pabrik, terkendala dengan permodalan. Pengamatan lapangan juga memperlihatkan bahwa sanitasi kandang juga belum baik yang ditunjukkan dengan belum adanya tempat penampungan kotoran. Selain itu, perhatian terhadap kesehatan ternak juga belum menjadi fokus bagi peternak. Peternak belum memahami bahwa kesehatan ternak sapi sangat penting diperhatikan karena bisa berpengaruh kepada produksinya.

\section{Solusi permasalahan rendahnya produksi susu sapi perah}

Permasalahan rendahnya produksi susu sapi di Kelompok Tani Sepakat II perlu ditangani dengan pendekatan yang tepat. Pada Gambar 1 terlihat bahwa terdapat empat alternatif penerapan teknologi untuk meningkatkan produksi susu sapi perah yaitu pengadaan induk baru, pembuatan konsentrat alternatif berbahan baku lokal, penanaman rumput unggul, dan penyuluhan teknologi terkait dengan sanitasi dan kesehatan ternak.

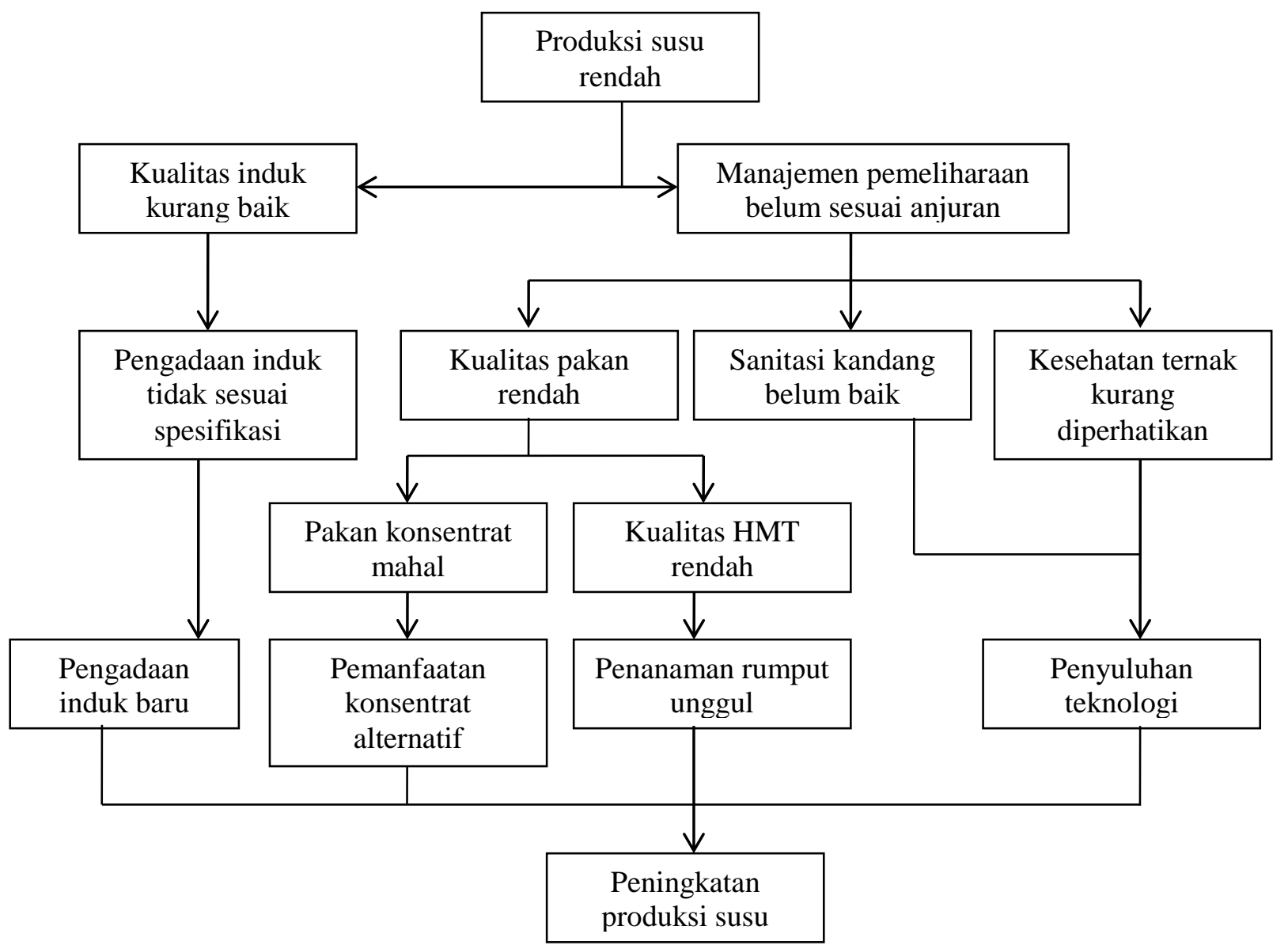

Gambar 1. Pohon masalah dan arah penyelesaian peningkatan produksi susu 
Pengadaan ternak diasumsikan sulit dilakukan petani karena harganya yang cukup mahal dan kesulitan dalam proses pembelian apabila hanya 1-2 ekor. Oleh karena itu, fokus peternak sapi perah hanya pada perbaikan pakan dan pemeliharaan ternak yang sudah ada. Alternatif peningkatan produksi susu sapi perah dengan pendekatan teknologi disajikan pada Gambar 2.

Dengan menggunakan metode Analitycal Hierarchy Process (AHP) yang diperoleh berdasarkan hasil FGD dengan 4 orang peternak di Kelompok Tani Sepakat II, diketahui bahwa petani lebih menekankan perlunya teknologi pemanfaatan konsentrat pakan yang bersumber dari bahan-bahan yang mudah dan atau murah diperoleh $(63,7 \%)$. Menurut petani, tanpa penggunaan konsentrat maka produksi susu tidak akan meningkat atau bahkan mempercepat penurunan atau kekeringan (kering kandang). Pemberian pakan dengan protein tinggi diharapkan akan meningkatkan konsumsi dan kadar bahan kering tanpa lemak susu. Peningkatan produksi susu diakibatkan karena adanya peningkatan kualitas ransum terutama protein. Hal ini sesuai dengan pendapat Susanti dan Marhaeniyanto (2007) bahwa produksi susu yang tinggi tekait erat dengan kualitas pakan yang dikonsumsi terutama protein. Pakan yang mengandung konsentrat tinggi akan meningkatkan produksi susu sapi perah, sedangkan pemberian hijauan dalam jumlah yang cukup akan berpengaruh terhadap kadar lemak susu, karena hijauan akan diubah oleh mikroba rumen menjadi VFA yang terdiri atas $65 \%$ asam asetat, $20 \%$ asam propionat dan $15 \%$ asam butirat (Barret dan Larkin 1979) dalam Riski.dkk 2016.

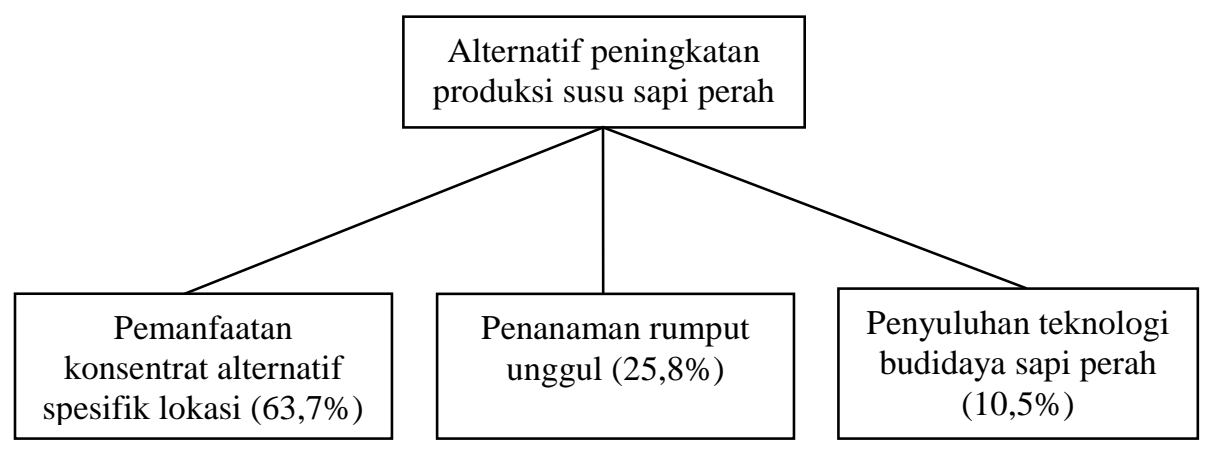

Gambar 2. Prioritas inovasi teknologi dalam rangka peningkatan produksi susu sapi perah di Kelompok Tani Sepakat II. 
King (2000) dalam Sumahati (2011) menyatakan bahwa potensi genetik akan muncul secara optimal yang disebabkan oleh peningkatan konsentrasi PK pakan untuk memenuhi kebutuhan mikroba rumen dalam mencapai produksi susu yang maksimal.

Peternak telah mencoba beberapa formulasi pakan yang disusun oleh BPTP Bengkulu dengan menggunakan bahanbahan yang ada di sekitar lokasi peternak. Hal ini bertujuan agar peternak kembali menggunakan konsentrat untuk meningkatkan produksi susu. Formulasi pakan konsentrat yang diberikan cukup mengandung nutrisi yang baik. Kadar protein konsentrat antara 13,3-17,5\% (Tabel 2).

Konsentrat I dan II ternyata memiliki kelemahan ketika diterapkan oleh petani. Konsentrat I tidak mampu meningkatkan produksi susu sedangkan konsentrat II kurang disukai oleh ternak. Dua tantangan formulasi konsentrat pakan ternak sapi perah yaitu bagaimana meningkatkan nilai gizi sekaligus palatabilitas sapi. Oleh karena saat ini sedang diujicoba konsentrat III.

Selain permasalahan teknis, pertimbangan ekonomi juga menjadi sesuatu yang penting di dalam menyusun ransum pakan. Peternak akan lebih memilih ransum konsentrat yang lebih murah. Tabel 3 menunjukkan perbandingan biaya produksi tiga formulasi pakan yang disusun BPTP Bengkulu. Formulasi tersebut sesuai dengan keinginan petani bahwa biaya produksinya tidak lebih dari Rp. $2.500 / \mathrm{kg}$ agar dapat diterapkan secara berkelanjutan.

Tabel 2. Perbandingan Kandungan Nutrisi Konsentrat Pakan Sapi Perah yang Telah Diujicoba (dalam $100 \mathrm{~kg}$ bahan).

\begin{tabular}{|c|c|c|c|c|c|c|c|}
\hline \multirow{2}{*}{ No. } & \multirow{2}{*}{ Uraian } & \multicolumn{2}{|c|}{ Konsentrat I } & \multicolumn{2}{|c|}{ Konsentrat II } & \multicolumn{2}{|c|}{ Konsentrat III } \\
\hline & & Volume & Nutrisi* & Volume & Nutrisi** & Volume & Nutrisi** \\
\hline 1. & Tongkol jagung & $1,97 \mathrm{~kg}$ & \multirow[t]{10}{*}{$\mathrm{PK}=13,3 \%$} & - & \multirow{10}{*}{$\mathrm{PK}=17,5 \%$} & - & \multirow[t]{10}{*}{$\mathrm{PK}=$} \\
\hline 2. & Solid & $2,96 \mathrm{~kg}$ & & 59,75 & & - & \\
\hline 3. & Kulit kopi & $59,19 \mathrm{~kg}$ & & $18,39 \mathrm{~kg}$ & & $18,75 \mathrm{~kg}$ & \\
\hline 4. & Dedak padi & $34,53 \mathrm{~kg}$ & & $3,04 \mathrm{~kg}$ & & $18,75 \mathrm{~kg}$ & \\
\hline 5. & Tepung ikan & - & & $13,58 \mathrm{~kg}$ & & - & \\
\hline 6. & Tetes & 0,25 liter & & 2,04 liter & & - & \\
\hline 7. & Garam & $0,6 \mathrm{~kg}$ & & $1,38 \mathrm{~kg}$ & & $0,3 \mathrm{~kg}$ & \\
\hline 8. & Kapur dolomit & $0,5 \mathrm{~kg}$ & & $1,45 \mathrm{~kg}$ & & & \\
\hline 9. & Ampas tahu & - & & - & & $62,50 \mathrm{~kg}$ & \\
\hline 10 & Mineral & - & & - & & $0,1 \mathrm{~kg}$ & \\
\hline & Jumlah & $100 \mathrm{~kg}$ & & & & & \\
\hline
\end{tabular}

Keterangan:

* Kandungan nutrisi berdasarkan perhitungan manual.

** Kandungan nutrisi berdasarkan hasil analisis Laboratorium Peternakan UNIB. 
Tabel 3. Perbandingan Biaya Produksi Tiga Formulasi Pakan Ternak Sapi BPTP Bengkulu (dalam $100 \mathrm{~kg}$ bahan).

\begin{tabular}{|c|c|c|c|c|c|c|c|c|}
\hline \multirow[b]{2}{*}{ No. } & \multirow[b]{2}{*}{ Uraian } & \multirow{2}{*}{$\begin{array}{c}\text { Harga } \\
\text { satuan (Rp.) }\end{array}$} & \multicolumn{2}{|c|}{ Konsentrat I } & \multicolumn{2}{|c|}{ Konsentrat II } & \multicolumn{2}{|c|}{ Konsentrat III } \\
\hline & & & Volume & $\begin{array}{l}\text { Jumlah } \\
\text { (Rp.) }\end{array}$ & Volume & $\begin{array}{l}\text { Jumlah } \\
\text { (Rp.) }\end{array}$ & Volume & $\begin{array}{c}\text { Jumlah } \\
\text { (Rp.) }\end{array}$ \\
\hline 1. & $\begin{array}{l}\text { Tongkol } \\
\text { jagung }\end{array}$ & $300 / \mathrm{kg}$ & $1,97 \mathrm{~kg}$ & 591,00 & - & 0,00 & - & - \\
\hline 2. & Solid & $710 / \mathrm{kg}$ & $2,96 \mathrm{~kg}$ & 1391,60 & 59,75 & $42.422,50$ & - & - \\
\hline 3. & Kulit kopi & $715 / \mathrm{kg}$ & $59,19 \mathrm{~kg}$ & $42.320,85$ & $18,39 \mathrm{~kg}$ & $13.148,85$ & 18,75 & 13.406 \\
\hline 4. & Dedak padi & $2.500 / \mathrm{kg}$ & $34,53 \mathrm{~kg}$ & 86.325 & $3,04 \mathrm{~kg}$ & 7.600 & 18,75 & 46.875 \\
\hline 5. & Tepung ikan & $5.300 / \mathrm{kg}$ & - & - & $13,58 \mathrm{~kg}$ & 71.974 & - & - \\
\hline 6. & Ampas tahu & $540 / \mathrm{kg}$ & - & - & - & - & $62,5 \mathrm{~kg}$ & 33.750 \\
\hline 7. & Tetes & 6.000/liter & 0,25 liter & 1.500 & 0,25 liter & $1.500,00$ & - & - \\
\hline 8. & Garam & $3.500 / \mathrm{kg}$ & $0,6 \mathrm{~kg}$ & 2.100 & $0,6 \mathrm{~kg}$ & 2.100 & $0,3 \mathrm{~kg}$ & 1.050 \\
\hline 9. & $\begin{array}{l}\text { Kapur } \\
\text { dolomit }\end{array}$ & $600 / \mathrm{kg}$ & $0,5 \mathrm{~kg}$ & 300 & $0,5 \mathrm{~kg}$ & 300 & - & - \\
\hline 10. & Mineral & $8.000 / \mathrm{kg}$ & - & - & - & - & $0,1 \mathrm{~kg}$ & 800 \\
\hline 11. & $\begin{array}{l}\text { Biaya } \\
\text { pembuatan }\end{array}$ & $200 / \mathrm{kg}$ & $100 \mathrm{~kg}$ & 20.000 & $100 \mathrm{~kg}$ & 20.000 & $100 \mathrm{~kg}$ & $20.000,00$ \\
\hline & Jumlah & & $100 \mathrm{~kg}$ & $154.528,45$ & $100 \mathrm{~kg}$ & $\begin{array}{r}173.085,3 \\
5 \\
\end{array}$ & $100 \mathrm{~kg}$ & 115.881 \\
\hline \multicolumn{3}{|c|}{ Biaya per kg } & \multicolumn{2}{|c|}{ Rp. 1.545} & \multicolumn{2}{|c|}{ Rp. 1.731} & \multicolumn{2}{|c|}{ Rp. 1.159} \\
\hline
\end{tabular}

Dari Tabel 3, peternak sapi perah di kelompok tani Sepakat II lebih cenderung untuk memakai konsentrat 3 (tiga) dengan beberapa alasan yaitu (i). Cara membuatnya rekatif mudah, (ii). Lebih disukai oleh ternak sapi perah dibandingkan dengan konsentrat 1 (satu) dan 2 (dua) dan (iii). Harga konsentrat 3 (tiga) lebih murah dibandingkan dengan konsentrat 1 (satu) dan 2 (dua).

\section{KESIMPULAN}

1. Alternatif pemecahan permasalahan untuk peningkatan produksi susu sapi perah di Kelompok Tani Sepakat II Desa Mojorejo Kecamatan Sindang Kelingi Kebupaten Rejang Lebong adalah dengan Pemanfaatan konsentrat alternatif spesifik lokasi dengan tidak mengabaikan kandungan nutrisi dan biaya yang terjangkau oleh peternak dari bahan pakan yang digunakan.

2. Pemilihan konsentrat yang akan digunakan bisa mempertimbangkan beberapa hal seperti (i). Tingkat palatabilitas ternak terhadap palatabilitasnya, (ii) cara mendapatkan bahan dan membuatnya, dan (iii). Harganya relatif lebih murah.

\section{DAFTAR PUSTAKA}

Ahmad, I. dan Hermiyetti. 2008. "Analisis Produksi dan Konsumsi Susu di Indonesia". Prosiding Seminar Nasional Prospek Industri Sapi Perah Menuju Perdagangan Bebas 2020. Jakarta. 21 April 2008. Pusat Penelitian dan Pengembangan Peternakan, Bogor 
bekerja sama dengan Sekolah Tinggi

Ilmu Ekonomi Keuangan dan Perbankan Indonesia.

BPS. 2018. Rejang Lebong Dalam Angka. Badan Pusat Statistik Kabupaten Rejang Lebong.

Handayani, R.I. 2015. Pemanfaatan Aplikasi Expert Choice Sebagai Alat Bantu dalam Pengambilan Keputusan (Studi Kasus: PT. Bit Teknologi Nusantara). Jurnal Pilar Nusa Mandiri 11(1):53-59.

Iriadi, N. dan D Yohana. 2016. Pengaruh Sistem Pendukung Keputusan dalam Pemilihan Mobil LCGC dengan Metode Analytic Hierarchy Process (AHP). Jurnal Khatulistiwa Informatika 4(2):173-181.

King. I. Jr. 2000. Managing the high genetic meric cow. Universitas Delaware. (PhD Disertasi).

Kusrini. 2007. Konsep dan Aplikasi Sistem Pendukung Keputusan.Yogyakarta : Andy Offset.

Riski. P, B. P. Purwanto dan A. Atabany. 2016. Produksi dan Kualitas Susu Sapi FH aktasi yang Diberi Pakan Daun Pelepah Sawit. Jurnal Ilmu Produksi dan Teknologi Hasil Peternakan. Vol. 04 No. 3 Oktober 2016 . Hlm: 345-349. ISSN 2303-2227

Sanyoto, G.P., R.I. Handayani, dan E. Widanengsih. 2017. Sistem
Pendukung Keputusan Pemilihan Laptop untuk Kebutuhan Operasional dengan Metode AHP (Studi Kasus: Direktorat Pembinaan Kursus dan Pelatihan Kemdikbud). Jurnal Pilar Nusa Mandiri 13(2):160-173.

Sumahati M, Isroli dan Widiyanto. 2011. Utiliti protein pada sapi perah Frisian Holtein yang mendapatkan ransum kulit kopi sebagai sumber serat kasar yang diolah dengan teknologi amoniasi fermentasi (Amofer). Laporan Penelitian. Vol 15 No.1, Juni 2011. ISSN 08539812. Fakultas Peternakan Universitas Diponegoro Semarang.

Susanti, S dan E. Marhaeniyanto, 2007. Kecernaan, Retensi Nitrogen dan hubungan dengan produksi susu pada sapi Peranakan Frisian Holtein (FH) yang dieri pakan pollar dan bekatul. http://ejurnal.umm.ac.id. Diakses 8 Oktober 2019.

Tawaf R. 2009. Sapi Perah Fries Holland. http://disnaksinjai.blogspot.com/201 1/09/sapi-perah-fries-holland.html. Diakses pada 10 November 2013

Walangare, D., R. Delima dan Restyandito. 2012. Sistem Prediksi Pertandingan Sepak Bola dengan Metode Analytical Hierarchy Process (AHP). Informatika 8(2):181-188. 